\title{
PENINGKATAN KOSAKATA BAHASA INGGRIS MENGGUNAKAN METODE GAME " SPELLING BEE" PADA SISWA KELAS VIII MTSN 7 KOTA PADANG
}

\author{
Dwi Megista Putri ${ }^{1}$, Rasmita $^{2}$, Dian Christina ${ }^{3}$ \\ ${ }^{123}$ Universitas Putra Indonesia YPTK Padang \\ Email: dwimegista18@gmail.com, rasmita@upiyptk.ac.id, \\ dianchristina746@gmail.com
}

\begin{abstract}
ABSTRAK
Kegiatan ini diusulkan dengan pertimbangan bahwa pada umumnya siswa pemula cenderung menyukai kegiatan belajar dengan tindakan dan gerakan yang berbeda. Masalah lainnya yang ditemui ialah siswa biasanya mudah bosan dengan aktifitas pemebelajaran setelah 10 menit dan menyebabkan rentang perhatian pendek dan kurangnya daya ingat. Berdasarkan permasalahan diatas, maka tim pengabdian masyarakat ingin memotivasi siswa untuk belajar bahasa Inggris dengan metode yang menarik dan tentunya disukai oleh siswa yaitu Spelling Bee. Kegiatan ini dilaksanakan sebagai umpan balik dari tindakan analisis kebutuhan yang telah dilakukan oleh tim pengabdi terhadap siswa MTSN 7 kota Padang. Diharapkan setelah kegiatan ini terlaksana, siswa mampu mengetahui bakat dan minat belajar di sekolah akan kebutuhan bahasa Inggris yang mana bisa diaplikasikan dalam kegiatan sehari-hari.
\end{abstract}

Kata kunci: Kosakata Bahasa Inggris, Metode Spelling Bee, Motivasi

\section{PENDAHULUAN}

Kemampuan seseorang menguasai suatu bahasa berkaitan erat dengan penguasaan kosakata dari bahasa itu sendiri. Mengenal dan mempelajari kata serta maknanya dari bahasa yang digunakan sangatlah penting. Jika mengalami kesulitan dalam memahami suatu bahasa bisa saja disebabkan oleh beberapa hal mendasar, salah satunya kurangnya pemahaman akan kosakata.Oleh karena itu berinteraksi, berkomunikasi dan saling bertukar informasi diperlukan perbendaharan kosakata yang baik.

Konsep pembelajaran bahasa Inggris tentulah berbeda dengan bahasa Indonesia. Penguatan konsep bahasa Inggris terutama kosakata bahasa Inggris lebih dituntut untuk dipelajari pada saat sekolah dasar dan sekolah menengah pertama. Kendala utama pembelajaran bahasa asing terdapat pada pengucapan /bunyi kata serta arti kata itu sendiri. Hal ini dapat dilihat pada dunia kerja yang mana sebahagian besar siswa yang telah menyelesaikan pendidikan tinggi masih belum mampu untuk menggungkapkan ide atau pendapat mereka dalam bahasa inggris karena terbatasnya kosakata yang dimiliki. 
Hal yang sering ditemui dalam pembelajaran bahasa Inggris terutama penguasaan kosakata bahasa Inggris yaitu dengan cara memorize (mengingat/menghafal). Metode tersebut tidak memberikan bukti nyata dalam kehidupan sehari-hari. Tanpa adanya pengaplikasian kosakata dalam bentuk lisan (percakapan sehari-hari) ataupu tulisan (seperti membuat surat) dalam bahasa Inggris maka apa yang telah dipelajari menjadi siasia.

Pada kenyataannya, pemahaman kosakata bahasa Inggris bagi siswa pemula (young learners) di sekolah menengah pertama sangat jauh dari keadaan ideal, yakni kurangnya pemahaman akan kosakata yang memadai serta belum mampu berkomunikasi dengan baik dalam berbagai konteks dan tema. Namun perlu diakui bahwa jumlah siswa yang berhasil menguasai Bahasa Inggris dari bangku sekolah menengah pertama sangatlah sedikit. Semakin banyak siswa yang tertarik mengikuti kursus informal yang menawarkan berbagai keunggulan metode dan sistem belajar yang berbeda dengan di sekolah, mulai dari jumlah siswa yang lebih sedikit, kegiatan belajar yang lebih menarik dan menyenangkan. Hal tersebut menjadi kegitan alternatif pengajaran bahasa Inggris yang dinilai lebih efektif dari pada di sekolah. Kelemahan inilah yang membuat proses belajar-mengajar bahasa Inggris di sekolah belum mencapai hasil yang maksimal. Sehingga siswa yang berasal dari keluarga mampu khususnya secara keuangan dapat mengikut pelajaran tambahan di tempat kursus.

Ketimpangan-ketimpangan yang terjadi dapat berakibat buruk bagi perkembangan siswa dalam belajar baik dari segi motivasi atau minat. Siswa yang merasa tidak mampu berbahasa Inggris di usia dini akan mudah putus asa dan beranggapan bahwa dirinya tidak memiliki keahlian apapun untuk menguasai bahasa asing. Mereka juga akan membangun sikap anti terhadap pelajaran ini sehingga sulit untuk menguasai bahasa ini nantinya.

Melihat kondisi diatas, kami kelompok Pengabdian Masyarakat UPI YPTK Padang khususnya dari dosen bahasa Inggris mengajukan diri untuk memberikan Edukasi kepada siswa-siswi MTSN 7 kota Padang yaitu kompetisi antar siswa menggunakan metode Spelling Bee. Kegiatan ini nantinya akan meminta keikutsertaan beberapa kelas pada tingkat yang sama.

\section{METODE}

Pada tahap ini tim telah menyiapkan materi pelajaran yang akan disampaikan kepada siswa. Metode yang digunakan ialah spelling bee yang mana aktifitas siswa lebih 
menekankan pada pendengaran (listening) dan pengejaan (spelling). Materi ajar bahasa Inggris yang akan digunakan dalam kegiatan pengabdian ini berupa daftar kata yang akan diujikan dalam kompetisi. Materi-materi tersebut diberikan berdasarkan hasil analisis kebutuhan terhadap siswa-siswi di sekolah menengah pertama.

Peserta kompetisi dilakukan dengan kategori yang sama yaitu seluruh siswa-siswi kelas VIII sekolah menengah pertama yaitu MTsN 7 Padang. Jumlah peserta yang direncanakan berjumlah 35 peserta pada masing-masing kelasnya. Hal penunjang kegiatan lainnya juga dibutuhkan seperti koordinasi dari pihak sekolah yang mana mengizinkan tim pengabdian kepada masyakat untuk kegiatan selama bulan Oktober dan November 2018. Para guru juga turut serta mengawasi siswa-siswi untuk ikut berpartisipasi dalam kegiatan ini.

Menjadi salah satu univesitas terbaik di Sumatera barat Universitas Putra Indonesia "YPTK" Padang saat ini membuktikan perannya bekerja sama dengan institusi lainnya baik dari segi pendidikan ataupun mitra usaha. UPI juga selalu aktif memotivasi dan menyemangati dosen-dosen dalam melaksanakan Tri Dharma Perguruan Tinggi. Dibawah naungan lembaga penelitian dan pengabdian kepada masyarakat, dosen-dosen dimotivasi untuk melakukan penelitian dan pengabdian kepada masyarakat tentunya secara sistematis dan terencana. Khusus untuk program studi bahasa Inggris, setiap tahunnya selalu melaksanakan pengabdian masyarakat yang berhubungan dengan bidang keahliaannya.

Tabel 1. Bidang keahlian/kepakaran dari tim pelaksana

\begin{tabular}{|l|c|l|}
\hline \multicolumn{1}{|c|}{ Bidang keahlian } & Tim Pelaksana & \multicolumn{1}{|c|}{$\begin{array}{c}\text { Bidang Keahlian/Mata } \\
\text { Kuliah yang Diampu }\end{array}$} \\
\hline $\begin{array}{l}\text { Ahli/pakar komunikasi lisan dan tulisan } \\
\text { bahasa Inggris, serta berpengalaman } \\
\text { menjadi juri dan pengajar kosakata bahasa }\end{array}$ & 1. Dwi & Reading I \\
Inggris UPI YPTK Padang & Megista & Writing I \\
& Putri, & Pronunciation \\
& Aplikasi Bahasa Inggris \\
& & \\
& 2. Rasmita, & Bahasa Inggris I \\
& M.Pd & Bahasasa Inggris I \\
& Brisgris II \\
& Christina, & \\
& M.Pd & \\
\hline
\end{tabular}




\section{HASIL DAN PEMBAHASAN}

Pelaksanaan kegiatan ini dilaksanakan selama 2 bulan. Rancangan pelaksanaan kegiatan spelling bee menurut Ur Penny (1995) bagi siswa siswi ialah sebagai berikut:

1. Anggota tim dari pengabdian kepada masyarakat berperan sebagai pembicara yang bertugas mengucapakn kata yang harus di eja dalam bahasa Inggris, berkata secara pelan dan diulang sebanyak 3 kali.

2. Siswa mendengarkan dengan seksama pembicara dan jika diperlukan meminta pengulangan untuk mengucapakan kata yang akan di eja/ualang.

3. Jika dirasa sudah benar paham dengan kata yang akan diucapkan, hal pertama yang akan dilakukan yakni mengucapkan kata secara keseluruhan, di eja dan diucapkan kembali secari benar.

4. Juri akan menentukan apabila ejaan benar atau salah.

5. Jika peserta benar, maka masih bertahan untuk mengikuti permainan tersebut.

6. Jika peserta salah, maka akan tereliminasi dari permainan dan juri memberikan jawaban yang benar.

7. Pembicara akan menlanjutkan ketahap selanjutnya.

8. Jika peserta yang tersisa hanya dua orang saja, maka akan dicari pemenang dari kompetisi ini.

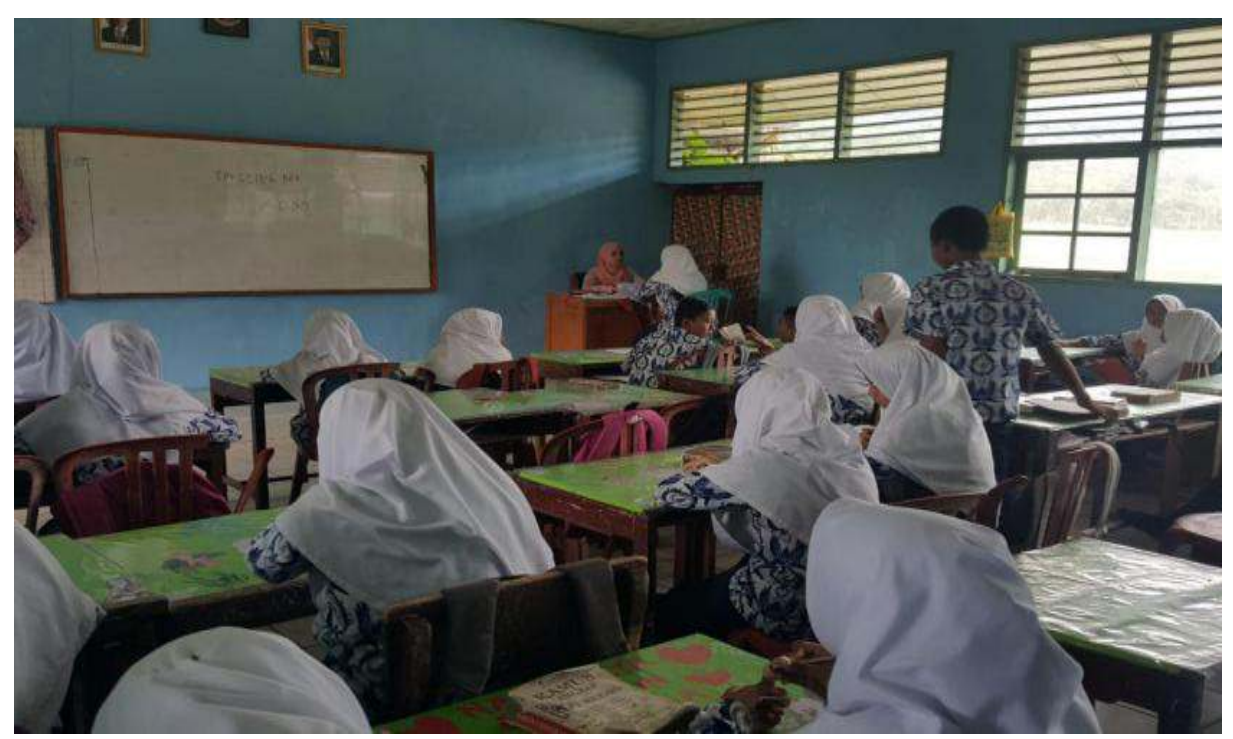

Gambar 1. Tahap Persiapan pada Masing-masing kelas 
Kegiatan yang dilaksanakan merupakan sebuah kompetisi pada setiap minggunya. Siswa tentunya akan diberikan tingkat kesukaran yang berbeda dan tema yang berbeda pula, meliputi ekonomi, sosial dan aktifitas sehari-hari. Kata-kata yang diujikan tentunya memberikan penambahan kosakata bahasa Inggris kepada siswa. Secara tidak langsung siswa bisa menerapkan kosakata yang mereka miliki kedalam kegiatan sehari-hari ataupun dalam pembelajaran formal disekolah.

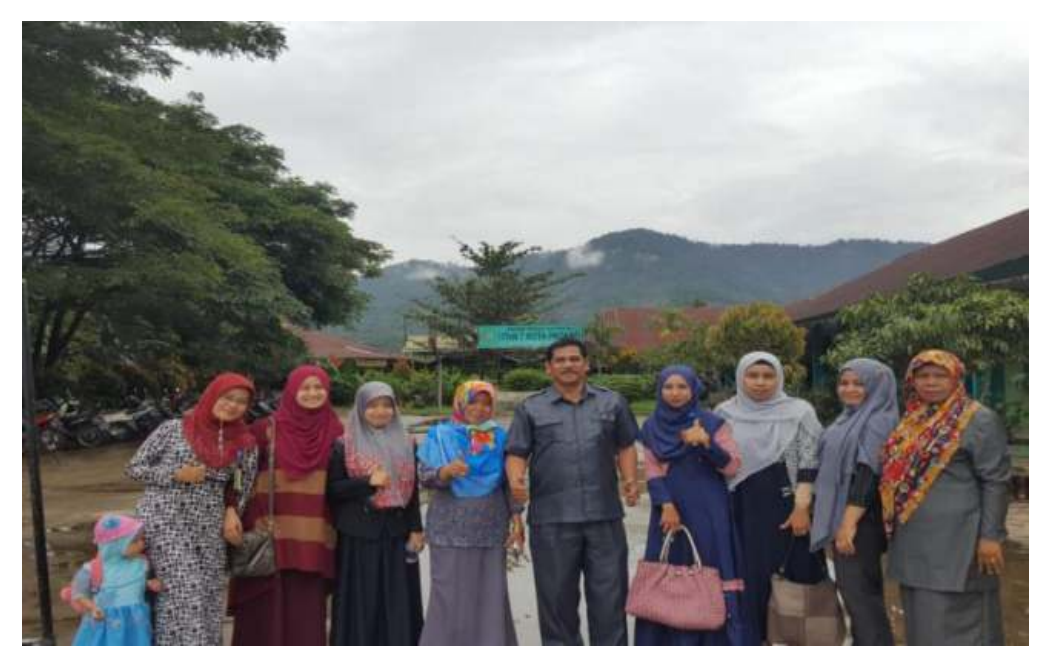

Gambar 2. Siswa akan di dampingi oleh 2 orang tim per kelas

Siswa dengan tingkat pemahaman yang baik di dalam pembelajaran bahasa Inggris tentunya tidak mengalami kesulitan dalam kompetisi Spelling Bee. Akan tetapi bagi siswa yang kurang memahami pembelajaran bahasa Inggris akan menghadapi kendala seperti terbata-bata dan menghabiskan banyak waktu untuk mengeja. Tim melihat bahwa siswa sangat antusias dalam mengikuti kompetisi ini. Dengan adanya penghargaan seperti tropi, uang tunai dan hadiah lainnya tentu saja siswa tidak ingin tinggal diam. Mereka berusaha mencapai penghargaan tersebut dan membawanya pulang.

Pada Tahap akhir pada kegiatan ini diumumkanlah juara pertama, kedua dan ketiga. Semua peserta yang mencapai target yaitu pada babak semi final juga mendapatkan hadiah menarik. 


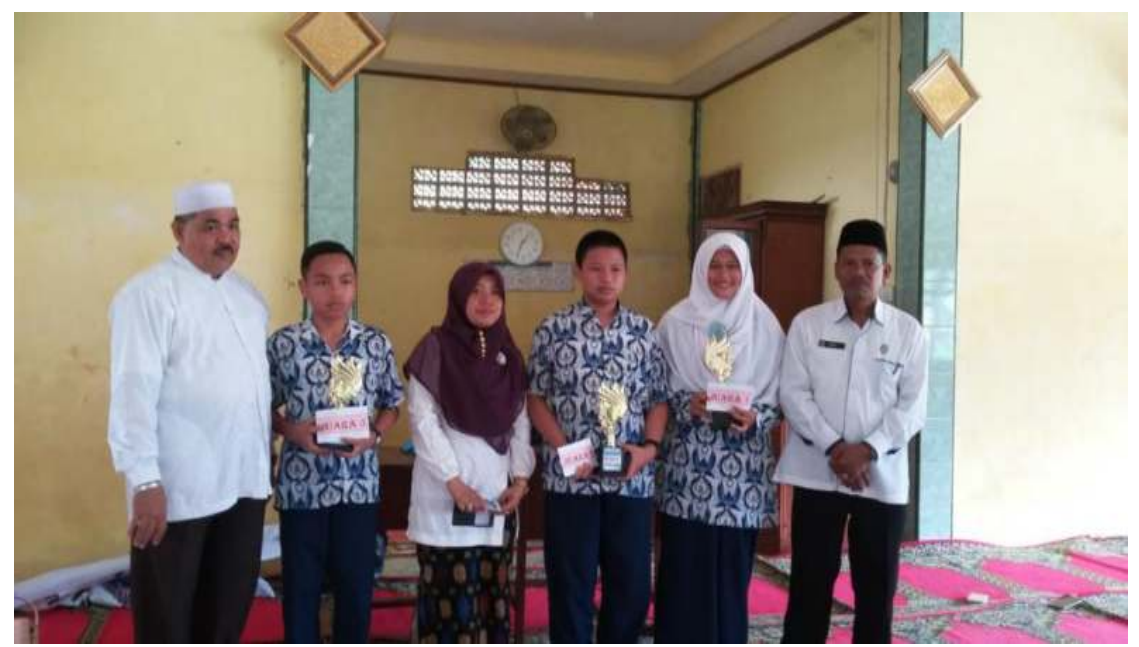

Gambar 3. Pemberian Hadiah

Tidak ketinggalan apresiasi yang disampaikan oleh pihak sekolah yaitu kepala sekolah MTsN 7 Padang yang mana sangat menginginkan kegiatan pengabdian kepada masyarakat untuk dilanjutkan. Lokasi sekolah yang bisa dikatakan sangat jauh dengan pusat kota yang mana melewati jalur pelabuhan kota Padang menyebabkan kurangnya partisipasi masyarakat terutama para akademisi menyalurkan ilmu pengetahuan, ide-ide pembelajaran dan juga pengalaman kepada siswa secara langsung.

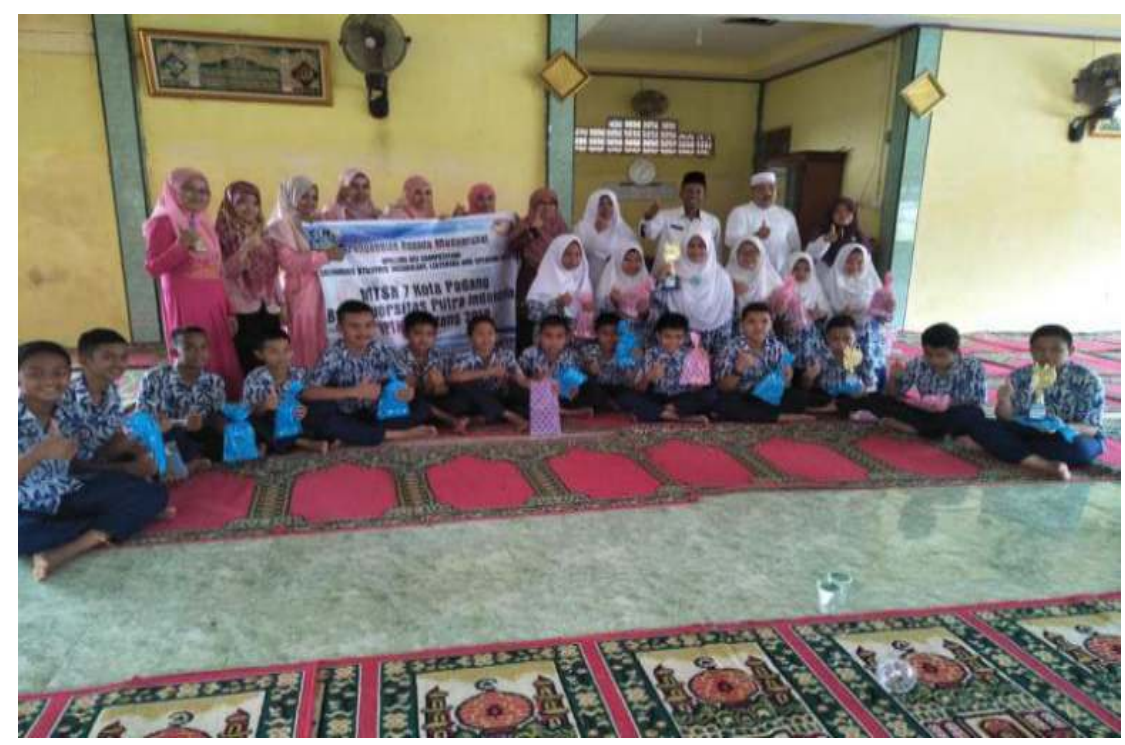

Gambar 4. Berfoto bersama setelah acara selesai 
Untuk itu tim menyampaikan rasa terima kasih atas keterbukaan dan izin kegiatan pengabdian ini. Semua pihak sekolah dari MTsN 7 Padang telah membantu sehingga terselenggaranya kegiatan dengan lancar dan baik.

\section{Partisipasi Mitra}

Setelah dilaksanakan kegiatan pengabdian kepada masyarakat maka tercapailah tujuan yang diinginkan. Dalam realisasi program tersebut mitra berpartisipasi dengan kegiatan menjadi peserta berupa ; menerima teori, konsep, serta hal-hal lain yang diberikan selama proses kegiatan berlangsung. Pihak sekolah menyediakan tempat, membeikan waktu dan fasilitas yang dibutuhkan selama proses kegiatan berjalan.

Keikutsertaan siswa yang mengikuti kegiatan ini pada setiap kelasnya sangat antusias. Siswa mencoba untuk tidak keluar kelas atau melakukan kegiatan lainnya diluar kelas karena rasa ingin tahu yang tinggi dan juga keinginan untuk terus belajar.

\section{KESIMPULAN}

Dari analisis situasi yang telah dijabarkan di atas dapat diambil kesimpulan akan permasalahan yang umum terjadi pada anak usia sekolah terutama sekolah menegah pertama dalam pembelajaran bahasa Inggris sebagai bahasa asing yang dituntut harus dikuasai oleh anak didik diantaranya adalah:

1. Kurangnya kepercayaan diri siswa yang menganggap bahasa Inggris sulit utuk dipahami sehingga anti terhadap pelajaran ini.

2. Rendahnya minat siswa untuk mempelajari bahasa inggris karena metode yang digunakan tidak menarik dan cenderung monoton.

3. Rendahnya penguasaan kosakata berbahasa Inggris siswa-siswi di sekolah menegah pertama karena kurangnya pengaplikasian kosakata dalam bentuk lisan atupun tulisan.

Menyikapi kepada hal-hal yang dijabarkan diatas, kegiatan pengabdian kepada masyarakat ini bertujuan untuk mengaplikasikan salah satu metode yang efektif dalam pembelajaran kosakata bahasa Inggris yang menarik dan disukai oleh siswa. Ketertarikan akan metode ini dipengaruhi oleh pentingnya proses pendidikan yang mengutamakan daya ingat yang kemudian membangkitan semangat untuk ingin belajar terutama bahasa Inggris. Selain itu, kegiatan ini juga bermanfaat bagi para pendidik/guru-guru tentang metode 
pembelajaran kosakata lainya sekaligus bisa digunakan untuk bidang studi lainnya. Dengan adanya kegiatan pengabdian masyarakat ini maka teraplikasikannya metode pengajaran Spelling Bee pada semua jenjang pendidikan, pembelajaran berorientasi pada siswa, termotivasinya siswa akan pentingnya bahasa Inggris, dan bertambahnya pengguasaan kosakata bahasa Inggris dalam arti luas.

\section{DAFTAR PUSTAKA}

Allen. (1999). Techniques in Teaching Vocabulary. New York: Oxford University Press

Merriam, Webster. (2016). Spell it! Tricks and Tips for Spelling Bee Success. New York: Merriam Webster

Paul David. (2003). Teaching English to Children in Asia. Hongkong: Pearson Education Asia Limited

Ur, Penny. (1995). Five Minutes Activities: A resource Book of Short Activities. Cambridge University Press 